\title{
Every breath we take
}

\author{
Rebecca Coombes head of news and views
}

The BMJ

Of all the risk factors for premature death, the air we breathe is one area over which patients and doctors have little control.

In cities health professionals care for patients in environments where air pollution can aggravate existing illness, mostly cardiovascular and respiratory disease, and also damage children's hearts and lungs as they develop.

Today we report that more than half of 2200 NHS facilities in London are blanketed in air pollution above legal limits (doi:10. 1136/bmj.j2855). This analysis by King's College London and the UK Health Alliance on Climate Change is further proof not only that London's air is toxic but that it harms the most vulnerable people. The same is likely to be true in other major cities around the world.

There is mounting evidence of harm linked to air pollutants, in particular fine particles and nitrogen dioxide. Last year the Royal College of Physicians and Royal College of Paediatrics and Child Health concluded that around 40000 deaths a year in the UK could be attributed to outdoor air pollution (https://www. rcplondon.ac.uk/projects/outputs/every-breath-we-take-lifelongimpact-air-pollution). Air pollution is now the world's fourth leading cause of death, a threat on an even bigger scale than HIV or Ebola virus disease.

The UK government has let us down, with no sense of urgency about solving this public health crisis. It has had to be harried by the courts to produce a plan to bring air pollution to within levels considered safe under European Union legislation (BMJ 2017;357:j2239). The latest draft plan dealt only with nitrogen dioxide, with no mention of particulates, which pose the main threat to health (doi:10.1136/bmj.j2713). Sadly, the new environment secretary, Michael Gove, has a poor voting record on green issues, with his appointment greeted as akin to putting King Herod in charge of a crèche.

So what can doctors do? This issue aims to provide inspiration. Stephen Holgate and Helen Stokes-Lampard urge doctors to spread the message about air pollution to the public, by talking to patients in the surgery or clinic, but also by joining campaigns such as this week's National Clean Air Day (doi:10.1136/bmj. j2814). They can also lead by example: using cars less and walking and cycling more. Look at how health professionals kickstarted a national movement on the risks of smoking back in 1950s, they urge.

In another derogation, the government has devolved most responsibility for delivering its clean air plan to local authorities. Robin Russell-Jones doesn't let them off the hook, calling for tougher action on motor vehicles, and he sets out a roadmap for action (doi:10.1136/bmj.j2713). In London's mayor at least we have a powerful public health advocate, fuelled by his personal experience of developing asthma as an adult. In an interview with The BMJ's editor in chief, Fiona Godlee, Sadiq Khan sets out a series of hard hitting measures (doi:10.1136/bmj.j2842); fellow regional leaders would do well to follow his lead. 